\section{Papilomavírus humano associado a lesões de cérvix uterina}

Com a finalidade de contribuir para um melhor conhecimento do eventual papel do Papilomavírus humano (HPV) na etiopatogênese do câncer cervical na região norte do Brasil, estudou-se a prevalência do vírus em 228 mulheres portadoras de lesões de cérvix uterina, atendidas no "Instituto Ofir Loiola" (IOL), em Belém, Pará, no período de março de 1992 a maio de 1996. As pacientes foram submetidas à biópsia de colo uterino, sendo o material coletado encaminhado para histopatologia e pesquisa de HPV por diferentes técnicas laboratoriais. Para fins de análise, as participantes foram distribuídas em 3 grupos, de acordo com o diagnóstico histopatológico. O grupo A foi constituído de 155 mulheres com carcinoma epidermóide invasor ou adenocarcinoma, o grupo B de 54 portadoras de neoplasia intraepitelial cervical grau II ou III (NIC II e NIC III) e o C, de 19 pacientes com cervicite crônica. Pelas técnicas de PCR e/ou hibridização por dot-blot, registraram-se prevalência de HPV em $70,3 \%, 63,0 \%$ e $36,8 \%$ das mulheres reunidas nos grupamentos $\mathrm{A}$, B e C, respectivamente. O tipo de HPV predominante, obtido por hibridizão por dot-blot, foi 0 16, representando $60,4 \%$ das amostras positivas do grupo A e 54,5\% daquelas do grupo B. Os HPVs tipo 16,18 e 33 representaram $71,4 \%$ dos detectados no grupo C. Em 155 das 228 amostras testadas por PCR, realizou-se também a técnica de hibridização in situ (HIS) com sondas para detectar HPV 6/11, 16/18 e 31/33/35. A prevalência de HPV registrada por essa técnica foi de $17,4 \%$, enquanto que por PCR observouse, nas mesmas amostras, percentual positivo de $65,2 \%$. No que diz respeito a outros fatores, também tidos como implicados no desenvolvimento de carcinomas e lesões precursoras em cérvix uterina, verificou-se que cerca de $40 \%$ das mulheres dos grupos A e B admitiram iniciação sexual precoce (com 15 anos ou menos). Entretanto, a grande maioria referiu de 1 a 3 parceiros, não caracterizando comportamento sexual promíscuo. Os dados aqui apresentados,

\section{Human papilloma virus associated with lesions of uterine cervix}

With the aim of improving our knowledge on the role of human papillomavirus (HPV) in the aetiopathogenesis of cervical cancer in Northern Brazil, it was studied the prevalence of HPV among 228 women with lesions of uterine cervix attending Ofir Loiola Institute, in Belem, Para, from March, 1992 to May, 1996. Histopathological examination was performed with all cervical biopsy sample obtained from these patients. In addition, specimens were analysed through different laboratory techniques to detect HPV DNA. The patients were assigned to three groups, according to the diagnosis made by histopathology, as follows: A, including women suffering from invasive epidermoid carcinoma or adenocarcinoma; B, 54 patients having either cervical intraepithelial neoplasia grade II or III (CIN II or CIN III); and C, involving 19 women with chronic cervicitis. Over all, the prevalence rates of HPV in groups $\mathrm{A}, \mathrm{B}$ and $\mathrm{C}$, as determine by PCR and/or dot-blot were $70.3 \%, 63.0 \%$ and respectively. HPV 16 predominated over other genotypes, accouting for $60.4 \%$ and $54.5 \%$ of types identified in groups $A$ and $B$, respectively. Altogether HPV types 16, 18 and 33 were detected in $71.4 \%$ of positive HPV patients belonging to group $\mathrm{C}$. The in situ hybridization (ISH) technique, including polyvalent HPV types $6 / 11,16 / 18$ and $31 / 33 / 35$ specific probes, was used to examine 155 of the 228 samples tested by PCR, yielding HPV-positive results in 17.4\% of them. Using this latter procedure, that is, PCR, the positivity rate was of much higher, $65.2 \%$, than that of $\mathrm{ISH}$. With regards to the potential HPV concurrent risck factors for the development of uterine cervical malignancies, it is noteworthy that $40 \%$ of women assigned to groups $A$ and $B$ reported having had first sexual intercourse when aged 15 years or less. During the interview, howewer, the number of lifetime sexual partners reported by most of them ranged from 1 to 3 , suggesting lack of promiscuity among the sampled patients. In general, our data accord with those from other studies carried out throughout the world,

Recebido para publicação em 21/01/98. 
a exemplo do que se registrou em outros estudos conduzidos em diversas áreas geográficas, sustentam a hipótese de que o HPV desempenha um importante papel na etiologia dos carcinomas de colo uterino e neoplasias intraepiteliais cervicais. Contudo, investigações adicionais e mais amplas devem ser realizadas, com vistas a uma melhor compreensão das características epidemiológicas da infecção por HPV na Região Amazônica. indicating that HPV plays a significant role in the aetiology of both cervical inttraepithelial neoplasia and carcinoma of the uterine cervix. Further and broader investigations should however be carried out, in order to better understand the epidemiological features of HPV infection in the Amazon Region.

Vânia Lúcia Noronha Cavalcante

Tese apresentada ao Núcleo de Medicina Tropical

da Universidade Federal do Pará para

obtenção do Título de Mestre.

Belém, PA, Brasil, 1997 